\title{
PERIASTRON RETICULATUM UNGER AND AEROCORTEX KENTUCKIENSIS, N. GEN. ET SP., FROM THE NEW ALBANY SHALE OF KENTUCKY ${ }^{1}$
}

\author{
Charles B. Beck ${ }^{2}$ \\ Department of Botany, University of Michigan. Ann Arbor 48109
}

\begin{abstract}
A B S T R A C T
Segments of anatomically preserved axes of the Lower Mississippian genus, Periastron, are analyzed in detail, and new features of histology and the pattern of vascular bundles are described. The name $P$. perforatum is shown to be a synonym of $P$. reticulatum. Division and fusion of vascular bundles in the axis result in variation in both their number (5-10) and form (in transverse section, from circular to elongate). In none of the 13 specimens studied is there any evidence of traces to lateral appendages, providing, with other evidence, support for the position that Periastron represents the petiole of a large leaf. Aerocortex kentuckiensis, a new name, is established for two specimens that resemble Periastron but which differ from it in being characterized by $2-4$ vascular bundles in contrast to the 5-10 (or 11?) of Periastron, and by having centrally, rather than peripherally, located secretory ducts. Aerocortex and Periastron might represent, respectively, proximal and distal regions of a petiole.
\end{abstract}

PERIASTRON RETICULATUM was established by Unger (1856) on the basis of a single specimen from the Lower Carboniferous (Unterculm) at Saalfeld in Thuringia. This specimen was restudied and accurately described by SolmsLaubach (1896).

A second species, $P$. perforatum, based on two fragmentary specimens collected from the Lower Mississippian New Albany shale near Junction City, Kentucky, was established by Scott and Jeffrey (1914). A third species, $P$. delepinei, was erected by Bertrand, Böhm, and Corsin (1935) and illustrated by Böhm (1935). This species is based on a poorly preserved fragment collected from the Lydiennes formation of the Montaigne Noire in southern France.

Periastron perforatum Scott and Jeffrey, as well as $P$. reticulatum Unger, was reported subsequently from the New Albany shale by Read (1936).

According to Cross and Hoskins (1951) the formations in which Periastron is known to occur are of similar Upper Devonian to Lower Mississippian age, with the exception of the Lydiennes Formation which may be slightly younger.

All workers agree that Periastron probably represents a petiole; but there is no general agreement, and in several cases, no published

\footnotetext{
1 Received for publication 23 May 1977, revision accepted 2 November 1977.

Supported by NSF grants GB-8100X and BMS75-14861.

${ }_{2}^{2}$ Appreciation is expressed to Dr. S. H. Mamay for loaning me slides of Periastron from the U.S. National Museum, and to Dr. John Pettitt for facilitating the loan by the British Museum (Natural History) of the type slides of $P$. perforcutum.
}

judgement on the taxonomic affinities of this unusual fossil plant.

The belief that it represents a petiole is based on its bilateral symmetry. The axis is of striking morphology, characterized by a single, approximately median row of vascular bundles on either side of which occur large and conspicuous lacunae, elongated radially as viewed in transverse section.

The species have been distinguished on the basis of only one or two characters. Periastron perforatum Scott and Jeffrey differs from $P$. reticulatum Unger only in the presumed absence of secretory ("gum") ducts, a prominent feature of the latter. Periastron delepinei, like $P$. perforatum, is thought to differ from $P$. reticulatum in lacking secretory ducts, and from $P$. perforatum in the smaller size of its lacunae.

The object of this paper is to present the results of a study of 13 specimens of Periastron and two Periastron-like specimens from the New Albany shale of Kentucky, USA. All specimens come from the Falling Run member of the Sanderson formation, considered by both Campbell (1946) and Haas (1956) to be basal lower Mississippian. Specimens 121, 261, 354 and 361 were collected from a roadside outcrop on the north side of U.S. route 62 , one mile east of Boston, Nelson County. Specimens 100, 104, 106, 271, $310,311,313,158$ and 159 were collected at Linietta Springs, just west of Junction City, Boyle County. Specimen 117 came from a roadside outcrop on route 68 about $1 \frac{1 / 2}{2}$ miles north of New Haven, Nelson County, and specimen 199 was collected at Pine Lick, one mile northwest of Loretta, Marion County.

The plant axes were preserved as cellular per- 
mineralizations in phosphatic nodules and, as is typical of plant fossils in this formation, their state of preservation is highly variable, often even within a single specimen. A feature of these fossils that adds to the difficulty of interpretation is the absence of mineral in the center of most cell cavities. Mineral has been deposited only in a variably thick region to the inside of the cell walls, or the cell layers bounding air cavities. Compounding the problem is the presence within these mineral accumulations of color lamellae, often closely simulating wall layers, and a crystal formation that sometimes gives the false impression of simple pits.

Seven of the 13 specimens have been studied in detail and provide the illustrations for this paper. Of these, 100, 104, 121, 158, and 271 are positively identified as Periastron, whereas 117 and 159 have many characteristics of Periastron but cannot be identified as such.

The type slides of $P$. perforatum Scott and Jeffrey were loaned by the British Museum of Natural History and the slides on which Read (1936) based his report of the occurrence of $P$. reticulatum and $P$. perforatum in the New Albany shale were loaned by the Smithsonian Institution. These materials were carefully compared with each other and with the specimens referred to above.

Periastron reticulatum-The gross pattern and general histological features of Periastron reticulatum were recorded by those who first described the genus (Unger, 1856; SolmsLaubach, 1896). Because subsequent workers have failed to provide any detail beyond that of the original descriptions, it is essential in this paper to describe the species in depth.

General features-The axis, which varies in transverse configuration from nearly circular to elliptical, is characterized by a more or less median, often slightly curved, row of vascular bundles, variable in number, that lie in a plane approximately parallel to the long, transverse axis of the elliptical specimens (Fig. 1, 3, 6, 7). The cortex on either side of the vascular bundles contains numerous and conspicuous air channels, commonly called lacunae, that are delimited by thin sheets of parenchyma (Fig. 1-3, 6, 7, 26, 29, $31)$. The outer cortex typically consists of a sclerenchymatous tissue of fiber-like cells in which a cylinder of secretory ducts is embedded
(Fig. 32). One specimen is characterized by secretory ducts that vary slightly in position from this typical condition.

Corte $x$-Only the most fragmentary remains of epidermis are occasionally preserved, but these provide a basis for determining the outer extent of the cortex which, at its periphery, consists of a sclerenchymatous zone of thick-walled, fiberlike cells that increase progressively in diameter toward the center of the axis and intergrade imperceptively in transverse section with cells of larger diameter, presumably parenchyma, that lie immediately outside the air channels (Fig. 26, 28 ). The outermost cortical cells have a diameter of about $30 \mu \mathrm{m}$ in contrast to a diameter of 177 $\mu \mathrm{m}$ for those just outside the air channels. This gradual increase in cell diameter is apparent in longitudinal view which, more significantly, shows also a distinct variation in cell morphology. The fiber-like cells are longitudinally elongate with transverse to tapered ends (Fig. 29, 35). These intergrade toward the interior of the axis with shorter cells that have oblique to truncate ends (Fig. 35). To the inside of, and continuous with, these cells is a zone of parenchyma cells of conspicuously different morphology, lying immediately outside the air channels. Cells of this zone are characterized by solely truncate ends and longitudinal dimensions only slightly greater than their transverse dimensions (Fig. 29,35).

The thickness of the tissue outside the air channels varies in the several specimens studied, but is thickest in the most nearly circular specimen (Fig. 3) and is narrowest at the ends of all the axes opposite the rows of vascular bundles.

Located in this tissue, usually in the peripheral sclerenchymatous zone, but in one specimen (271) just inside this zone, there is a cylinder of apparently discrete, secretory ducts (Fig. 32). These secretory ducts extend longitudinally (Fig. 35,42 ) for relatively great distances (up to $4 \mathrm{~cm}$, at least) without interconnection. In transverse view they vary in shape from elliptical to nearly circular (Fig. 32-34, 40), and in diameter from about 114 to $153 \mu \mathrm{m}$ in greatest dimension. Along its longitudinal extent a secretory duct may vary in greatest transverse dimension by as much as $17 \mu \mathrm{m}$, although variation is usually no more than $7 \mu \mathrm{m}$. There is also variation in size, relative to position, that appears to be consistent within several individual specimens. In specimen 271, for example, the 3 or 4 secretory ducts opposite

Fig. 1-7.-Fig. 1-3, 6, 7. Periastron reticulatum. Specimens from several localities showing general features such as variation in transverse size and form, size and distribution of cortical lacunae, and number and form of vascular bundles. 1. Slide 158-14. 2. Slide 121-4. 3. Slide 271-7. 6. Slide 100-4. 7. Slide 104-9.-Fig. 4, 5. Aerocortex kentuckiensis. 4. Slide 117-4. 5. Slide $159-2$. All $\times 5.5$. 

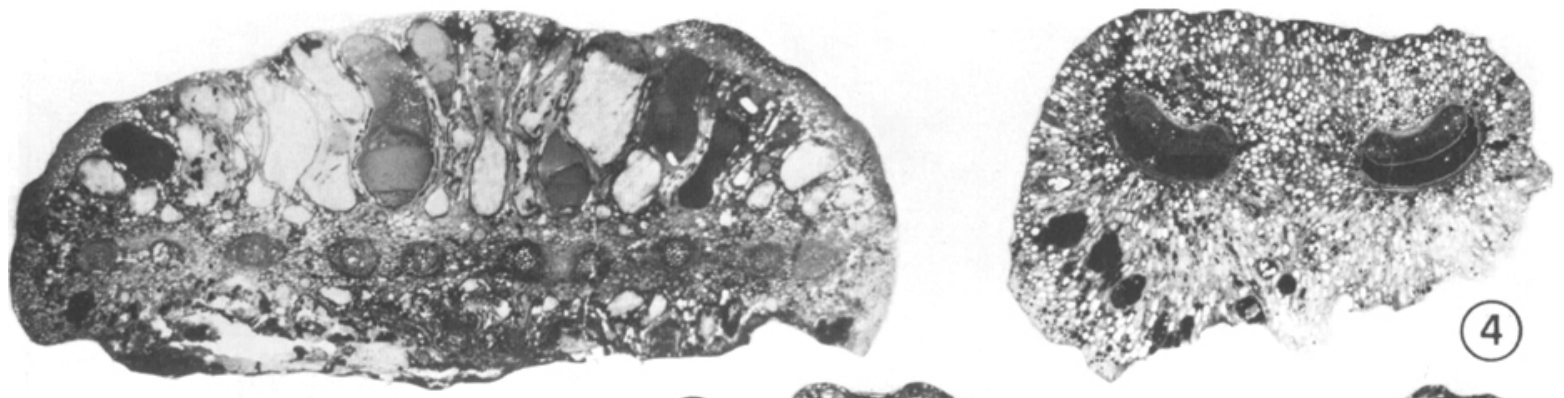

(1)
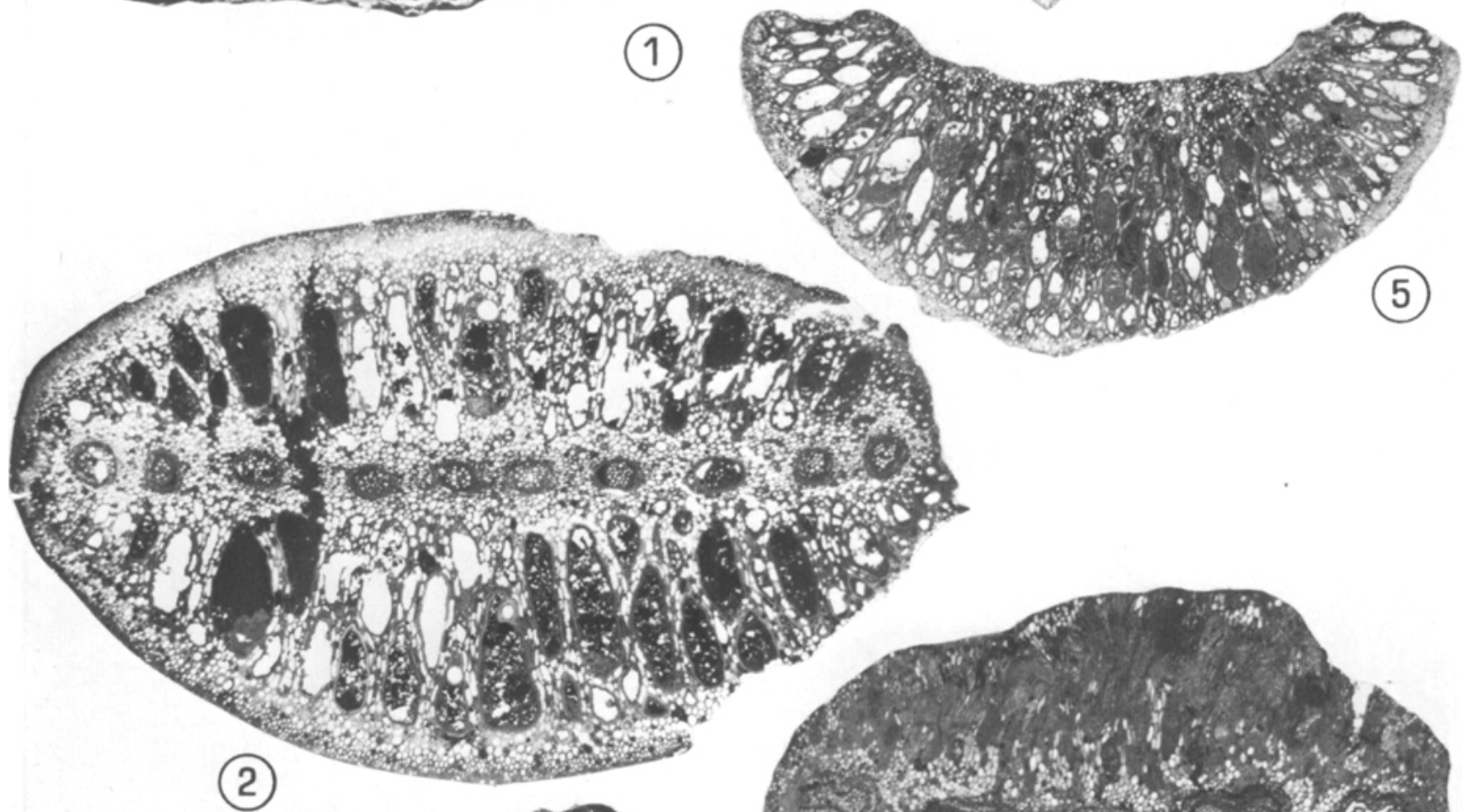

(2)

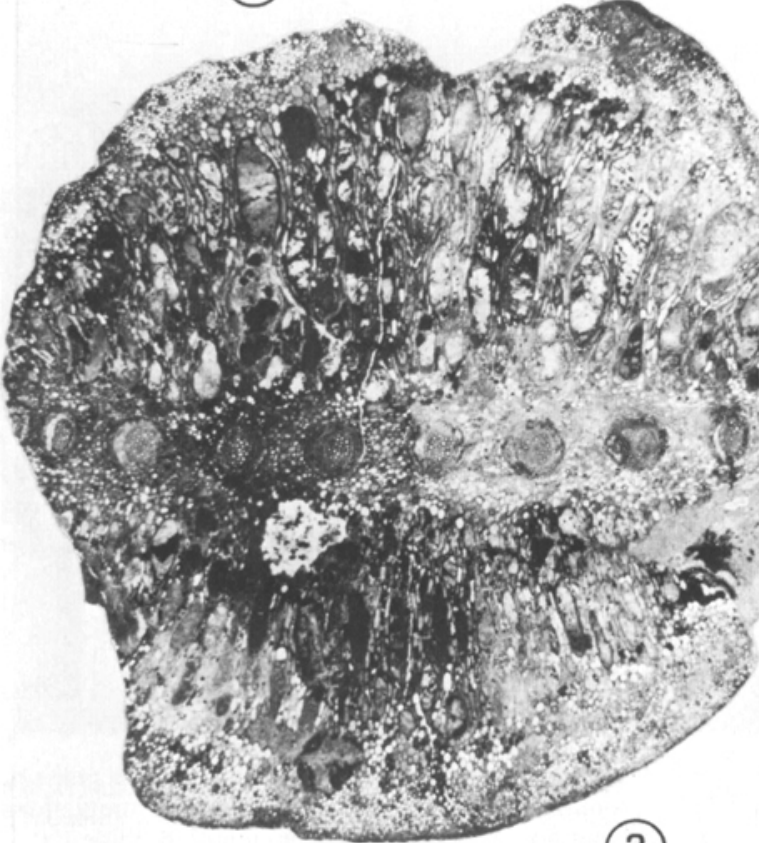

(3)

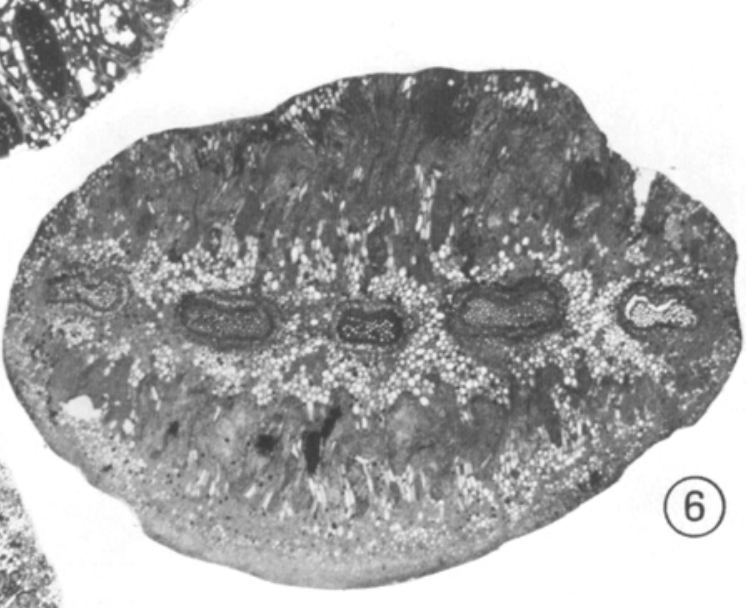

(6)
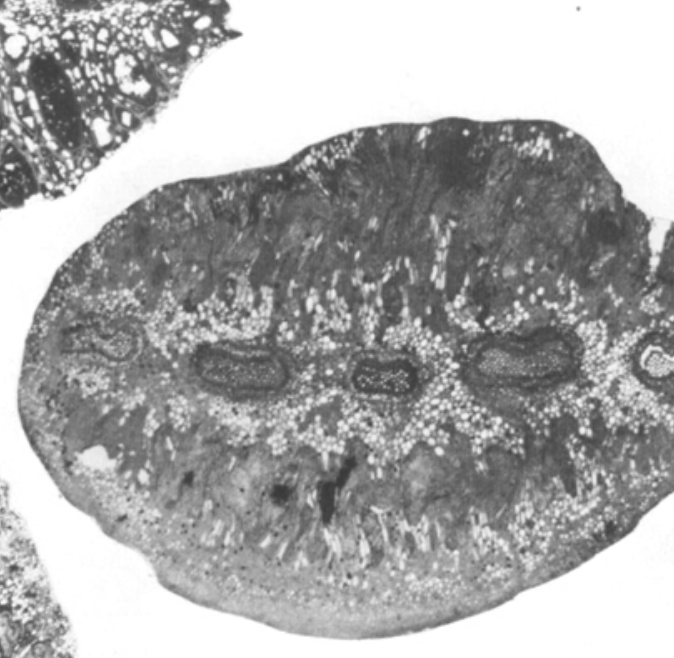

(5)
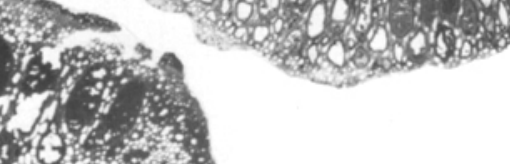

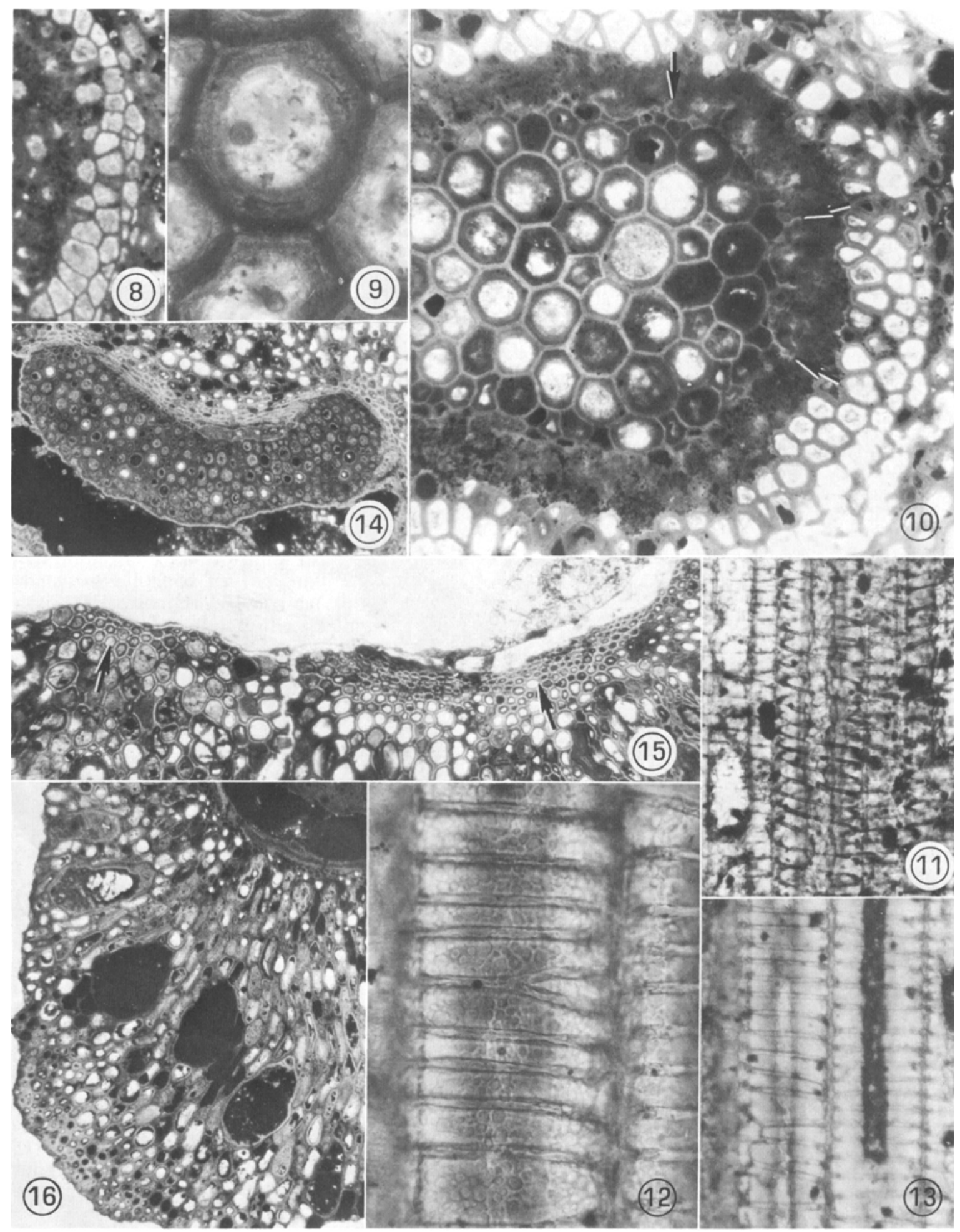

Fig. 8-16.-Fig. 8-13. Periastron reticulatum. 8. Transverse section of well-preserved tissue, presumably the phloem, located between the primary xylem and bundle sheath. $\times 110.9$. Tracheid lumina lined with peripheral mineral accumulations simulating thick cell walls. Organic wall substance appears dark. Small, circular bodies in cell lumina unidentified. Slide 100-5. $\times 340$. 10. Part of a vascular bundle, in transverse section, showing primary xylem (cell walls light). Note marginal fragments of thin-walled cells (arrows) representing, probably, protoxylem and/or phloem extending into a region lacking preservation, and the surrounding, conspicuous bundle sheath. Slide 100-1. $\times 110$. 11. Tracheids with helical sculpturing. Slide $271 \mathrm{~L}-7 . \times 210$. 
the ends of the row of vascular bundles have the smallest transverse dimensions (Fig. 43). Of the remaining, those above the slightly concave side of the row of bundles are smaller (averaging 134 $\mu \mathrm{m}$ in greatest transverse dimension) than those below it (which average $153 \mu \mathrm{m}$ in greatest transverse dimension $\left.{ }^{3}\right)$.

The secretory ducts seem each to consist, commonly, of a layer of large, thin-walled cells surrounding a central channel (Fig. 40, 44b). This channel varies from relatively small to relatively large and its size seems to be correlated with the transverse dimensions of the secretory ducts. Some regions (along the longitudinal extent) of some ducts may lack the central channel entirely which in these is replaced by a parenchyma cell (or row of such cells) (Fig. 44a). Where the channel is large, the peripheral cells are conspicuously narrow in radial dimension (i.e., in radial relation to the mid-point of the duct as viewed in transverse section) and such ducts are sometimes filled with a dark, granular material of unknown origin (Fig. 34). This variation in morphology of the ducts is probably related to developmental variation, but could in part be caused by variation in preservation.

Immediately surrounding the thin-walled cells, the presumed secretory cells of these ducts, is a cylinder of cells, fiber-like in transverse view, but longitudinally rather short and with tapered to truncate ends (Fig. 36, 42). These cells, which are of smaller diameter and have slightly thinner walls than those immediately surrounding them, form an indistinct sheath around the secretory ducts (Fig. 40, 44a, b).

A feature equally as interesting as the secretory ducts is the conspicuous system of air channels (Fig. 1-3, 26, 27). Longitudinally, the channels extend for great distances, but I have found no evidence of anastomosis. As one observes them in a series of sections, it is apparent that their transverse form and dimensions may fluctuate, but their relative positions remain constant. In cross section their longest dimensions are anticlinal, and the largest channels occur on

\footnotetext{
${ }^{3}$ The figure for mean size of secretory ducts above the row of bundles is based on 25 measurements, that for ducts below is based on 38 measurements. The total of 63 measurements combines approximately equal numbers of measurements from four levels (slides 1, 4, 7, and 18) throughout the longitudinal extent of the specimen.
}

either side of the central point in the row of vascular bundles (Fig. 1-3). From these regions the channels decrease in size gradually toward the regions opposite the ends of the row of vascular bundles where they are smallest in mean size (Fig. 27). Some of similar, small size, however, also occur elsewhere, especially along the periphery of the region of air channels (Fig. 26).

Separating the air channels are sheets of thinwalled parenchyma cells, one to five cell layers wide (Fig. 36, 41). Individual cells in these sheets are characterized by a long dimension of approximately $395 \mu \mathrm{m}$ oriented at right angles to the surface of the axis (Fig. 26, 30), the periclinal and longitudinal dimensions being approximately identical $(76 \mu \mathrm{m})$ and short by contrast (Fig. 30, 41). The cells are thus somewhat brick-like, but occasionally exhibit oblique or wedge-shaped ends. Between the small air channels at the ends of the rows of vascular bundles, the sheets of cells are very short, anticlinally, and the constituent cells essentially isodiametric (Fig. 27), varying, thus, from the condition described above.

Vascular system-In most specimens the row of vascular bundles is slightly curved, forming a very shallow arc as viewed in transverse section (Fig. 2, 3, 6, 7, 17, 21), but occasionally the row follows a nearly straight line (Fig. 1). The five to ten (or more) bundles are embedded in a plate of parenchyma tissue, designated by Scott and Jeffrey (1914) as the median band (Fig. 1-3, 6, 26, $31)$. The thin-walled cells of this region are essentially isodiametric (Fig. 26, 31). Individual bundles vary in transverse configuration from circular (Fig. 1-3) to elongate (in the plane parallel to the row of bundles). These elongate bundles may be slightly curved (Fig. 6) and exhibit from 1 to 3 longitudinal grooves which are more prominent along one surface than the other (Fig. 6, 18, 21, 23). A similar configuration characterizes the primary xylem strand of these bundles. Bundles with one groove on a side seem to be partially divided into two units, those with 2 grooves, into three units, and those with 3 grooves into four units (Fig. 6, 23). I shall present evidence subsequently which suggests that these configurations are directly related to either branching or fusion of the vascular bundles.

In transverse dimensions, the circular bundles

12. Tracheids characterized by scalariform bars over a thin, outer wall of reticulate appearance. Slide $271 \mathrm{~L}-9 . \times 513.13$. Tracheids with scalariform to scalariform-reticulate wall sculpturing. Slide $271 \mathrm{~L}-9 . \times 210$.-Fig. 14-16. Aerocortex kentuckiensis. 14. Vascular bundle showing constriction proximal to presumed division. Slide 117-1. $\times 31$. 15. Fragments of bundle sheaths (arrows), indicating positions of two vascular bundles of the approximate size and shape of those that would result from branching of a bundle such as that illustrated in Fig. 14. Slide 159-5. $\times$ 31. 16. Details of cortex, showing air channels. Slide 117-4. × 17. 

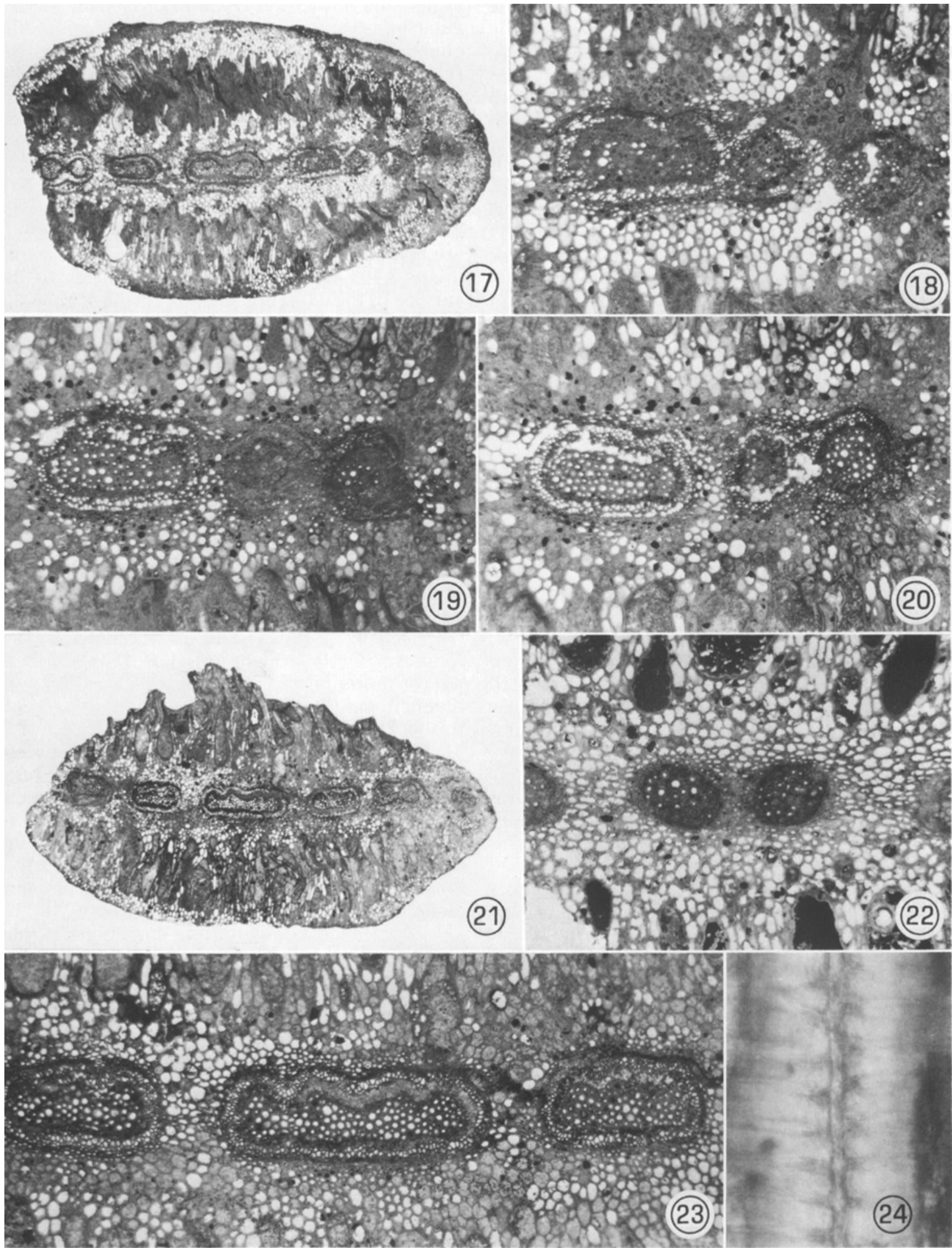

24

Fig. 17-24. Periastron reticulatum. 17. Transverse section from a region of vascular bundle division and fusion. Slide 104-1. $\times 5.5$. -Fig. 18-20. Details of bundle division and fusion. See test for detailed description. $\times 17.18$. Slide $104-1.19$. Slide 104-3. 20. Slide 104-4. 21. Section distal to levels of division and fusion shown in Fig. 17-20. Compare with Fig. 17 to observe variation in form of bundles. Refer to text for more detail. Slide 104-14. $\times 5.5$. 22. Two bundles embedded in a 
(of different specimens) vary in mean diameter from 791 to $1,103 \mu \mathrm{m}$. One and two-grooved bundles are approximately $1,800 \mu \mathrm{m}$ in greatest transverse dimension, whereas three-grooved bundles measure, at a maximum, $2,703 \mu \mathrm{m}$ in this dimension.

Vascular bundles-The bundles (Fig. 10, 23) are amphicribral, with phloem enclosing the xylem, and show no evidence of a vascular cambium or secondary growth. Each bundle is enclosed by a conspicuous bundle sheath.

Primary xylem consists of relatively thinwalled tracheids, polygonal in transverse outline (Fig. 10). These cells which average $66 \mu \mathrm{m}$ in diameter are of similar size and shape throughout the strand, becoming only slightly smaller in diameter at the periphery. The order of maturation of primary xylem cannot be determined, but was probably exarch.

Lateral wall sculpturing of the tracheids is either helical (Fig. 11) or scalariform, with some tendency toward becoming reticulate (Fig. 12, 13). An outer wall layer on which the scalariform thickenings are deposited is characterized by a fine, reticulate pattern (Fig. 12). Although most conspicuous in the walls of tracheary cells, and resembling the reticulate pit membranes described in several Devonian and Pennsylvanian genera, similar patterns have been observed in non-tracheary cells such as cortical parenchyma and the elongate cells of the bundle sheaths. This suggests that the fine, reticulate pattern may be a general characteristic of the primary and/or outer secondary walls of this plant and, further, one that may appear only upon wall degradation, thus, not a visible feature in the living plant. The possibility that this pattern is an artifact reflecting the crystal form of some mineral in the sections also cannot be ruled out.

Occasionally on the surface of the xylem one observes a narrow layer of smaller, thin-walled, often fragmentary cells (Fig. 10). The innermost of these may be xylem parenchyma, whereas the larger probably represent the phloem. The region between the xylem and bundle sheath is nearly always devoid of well-preserved tissue (Fig. 10), but rarely contains rather large, thin-walled cells, rectangular to more highly polygonal in transverse configuration (Fig. 8) that have an average, greatest dimension of $36 \mu \mathrm{m}$. These cells resemble the sieve cells of pteridophytes. Unfortunately, they have not been observed in longitudinal view.
The bundle sheath, 3-5 cell layers thick, consists of relatively thick-walled, sclerenchymalike cells that are polygonal in transverse configuration (Fig. 10) and have a mean diameter of 39 $\mu \mathrm{m}$. They have a longitudinal dimension of approximately $262 \mu \mathrm{m}$ and are characterized by truncate to oblique ends.

The pattern of vascular bundles-The variable number and morphology of vascular bundles alone suggest division of bundles within the vascular system. Two specimens, 100 (Fig. 6) and 104 (Fig. 17-21, 23), which almost certainly represent consecutive (or nearly consecutive) segments of the same axis, provide positive evidence of both division and fusion, and seem to represent a region between two levels of an axis, one containing fewer than 5 and the other, 9 or more bundles. I conclude that these specimens represent the same axis because they were collected from within several centimeters of each other, are very similar in transverse form and dimension, and exhibit the same type of compression damage in the tissue along one side. Furthermore, the configuration of the vascular bundles of specimen 100 (Fig. 6) is consistent with the pattern of the bundles in specimen 104 (Fig. 17-21).

The two outermost bundles of specimen 100 are deeply grooved in a manner that suggests the departure, to the inside, of strands of circular, transverse configuration (Fig. 6, 46). At the base of specimen 104, a series of sections (Fig. 17-21) shows a new vascular bundle, circular in transverse view, (Fig. 18, far right; apparently the product of division of a marginal bundle of specimen 100) and its fusion with an adjacent bundle (Fig. 19, 20) which originated from the bundle to its left (Fig. 18).

The presence of a "double" bundle (Fig. 17, far left) in an equivalent position at the opposite end of the row of vascular bundles, and its change in configuration through a series of slides provides convincing evidence that the same pattern of bundle division and fusion had also occurred there, at a slightly lower level.

Over a distance of about $3 \mathrm{~cm}$, represented by 18 serial sections, other changes take place in specimen 104. The central bundle, which is the largest, and the bundles on either side of it, are similar in form to the comparable bundles of specimen 100 (Fig. 6), i.e., elongate in the plane of the greatest transverse dimension of the axis, and with a shallow groove along one side (Fig.

common bundle-sheath, suggesting that the section is from a level just proximal to fusion or just distal to division. Slide 121-1. $\times 17$. 23. Enlargement showing form of vascular bundles illustrated in Fig. 21 at a slightly different level. Note conspicuous ridges and grooves. Slide 104-16. $\times 17$. 24. Sectional views of scalariform bars in tracheids of primary xylem. Slide 271-9. $\times 513$. 
17). At the distal end of the axis segment, however, these three bundles have become conspicuously modified in form-the central one having attained three conspicuous grooves and four ridges along one side, each of the flanking bundles, two grooves and three ridges (Fig. 23). These configurations characterize both surfaces of the bundles, but are prominent on only one. They are most conspicuous in the primary xylem. Change in bundle configuration is accompanied by an increase in the greater dimension of the bundles which, together, suggest a probable division of these bundles at a higher level. At the most distal level of this axis, there are seven vascular bundles (Fig. 21), the central three of which have just been described. Just outside these on either side are the bundles formed by the division and fusion process described above. At their most distal levels these latter bundles are clepsydroid in form (Fig. 21) as are also the two marginal bundles which, however, are the smallest of the seven.

This entire process of division, fusion and change in configuration of bundles is illustrated diagrammatically in Fig. 46.

Synonymy of Periastron perforatum with $P$. reticulatum-Scott and Jeffrey (1914) established Periastron perforatum on the basis that it differed from $P$. reticulatum in a single characterthe absence of secretory ducts. My examination of the type material of $P$. perforatum has demonstrated the presence of secretory ducts in two of the four sections (slides $2898 \mathrm{~Eb}$ and $2899 \mathrm{E} 23$ ). The outermost layers of the other sections were too poorly preserved to show such detail. Five secretory ducts are clearly distinct and relatively well-preserved in one section (Fig. 38, 40), thus removing the presumed distinction upon which $P$. perforatum was separated from $P$. reticulatum.

The slides upon which Read (1936) based his report of the presence of both $P$. perforatum and $P$. reticulatum in the New Albany shale were also examined. Of the seven specimens, five (represented by 32 sections) possess peripheral secretory ducts and two (represented by only 4 sections) are too fragmentary and poorly preserved to identify to species.
In the absence of other known differences in the specimens to which the name has been assigned, Periastron perforatum Scott and Jeffrey must be placed in synonymy with Periastron reticulatum Unger.

Periastron reticulatum Unger. 1856. Zweiter Theil Schiefer und Sandsteinflora. In Richter, R., and F. Unger. Beitrag zur Paläontologie des Thüringer Waldes. Denkschr. Kaiser. Akad. Wiss. Wein 11: 139-186.

Periastron perforatum Scott and Jeffrey. 1914. On fossil plants, showing structure, from the base of the Waverley Shale of Kentucky. Phil. Trans. Roy. Soc. London 205B: 315-373.

Periastron. Emended diagnosis-Vascular plant axis, varying in transverse configuration from nearly circular to elliptical. Vascular bundles amphicribral, with conspicuous bundle sheaths, forming a straight or more often slightly curved median row; variable in number from five to ten (or more?), and in transverse form from circular to elongate in the plane of the row of bundles. Elongate bundles variously grooved, conspicuously so on one side. Variation in number and form related to division and fusion of bundles. Protoxylem inconspicuous, probably exarch in order of maturation. Cortex primarily aerenchymatous, characterized, except in its periphery, by numerous conspicuous, longitudinal air channels (lacunae) of variable size and transverse form separated by sheets, often very thin, of radially elongate parenchyma cells. Peripheral cortical tissue sclerenchymatous, becoming parenchymatous to the interior, and lacking lacunae. Secretory ducts, extensive longitudinally, forming a cylinder, sometimes irregular, in the outer cortex.

Periastron delepinei, like $P$. perforatum is based, in part, on a negative character, the apparent absence of secretory ducts. But since the specimen to which this name has been applied is so fragmentary (consisting of only a longitudinal sliver representing, at most, one half of the axis segment), so poorly preserved and, furthermore, based on only one section, this apparent absence of a structure is meaningless. We do not know, therefore, whether the specimen differed from $P$. reticulatum in this aspect. The specimen was de-

Fig. 25-31. 25. Aerocortex kentuckiensis. Details of cortex showing sclerenchymatous peripheral region (bottom), distribution and transverse configuration of air channels, and distribution of secretory ducts (between air channels and upper margin). Slide 159-2. $\times$ 18.-Fig. 26-31. Periastron reticulatum. 26. Transverse section illustrating median plate of parenchyma tissue containing vascular bundles, and surrounding aerenchyma. Slide 158-21. $\times 18.27$. Details of cortical tissues opposite one end of the row of vascular bundles. Region of air channels restricted in radial extent; air channels are smaller than those located elsewhere. Slide 158-5. $\times 31$. 28. Outer cortex, showing peripheral sclerenchyma and larger, thinner-walled cells just outside region of air channels. Slide 158-16. $\times 49$. 29. Longitudinal view parallel to septae between air channels. Slide $271 \mathrm{~L}-7 . \times 15$. 30. Detail of cells of septae between air channels as seen in longitudinal view similar to that in Fig. 29. Slide $271 \mathrm{~L}-1$. $\times 30.31$. Median plate of parenchyma tissue containing vascular bundles seen in longitudinal section. Slide 100-14. $\times 15$. 


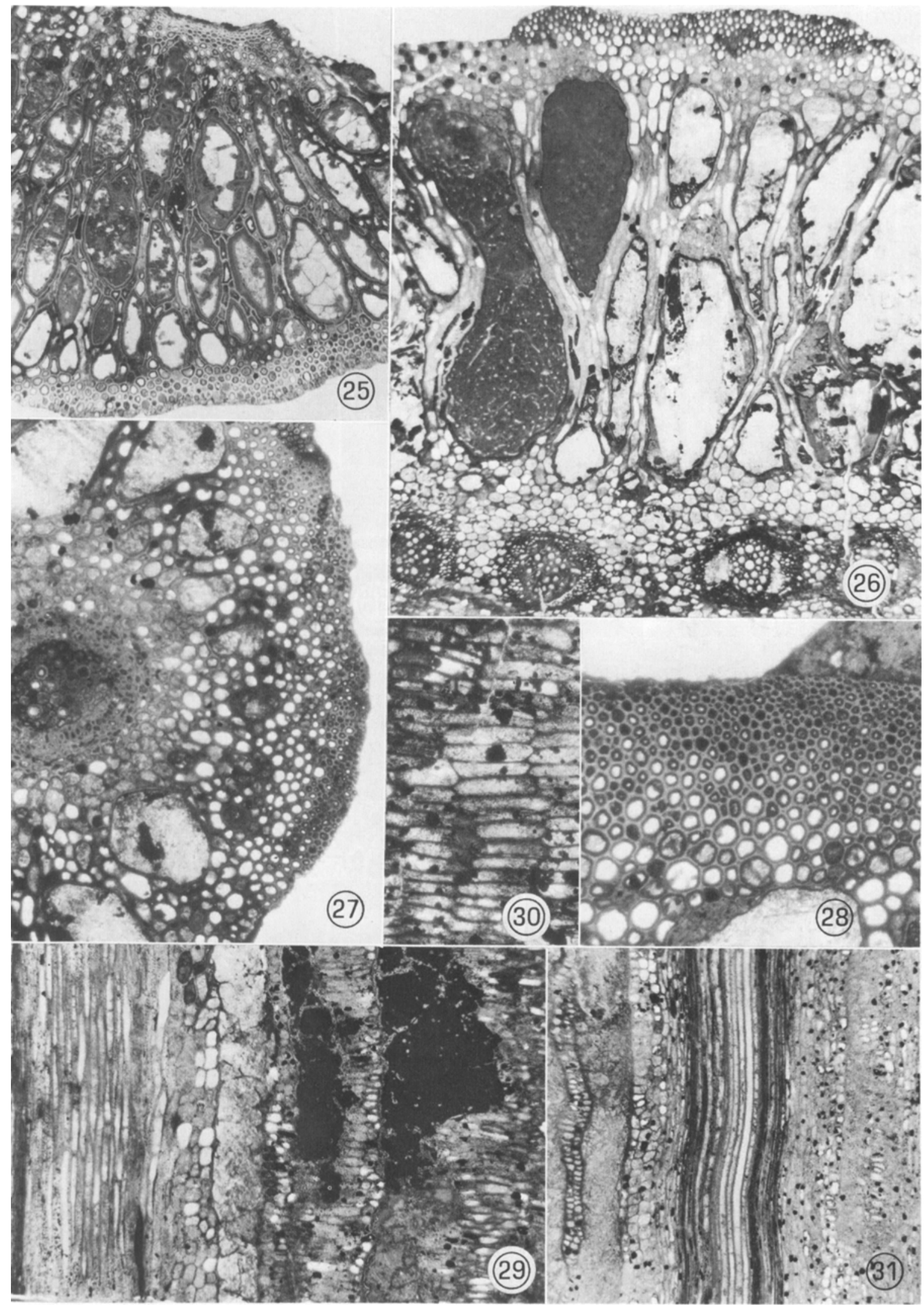




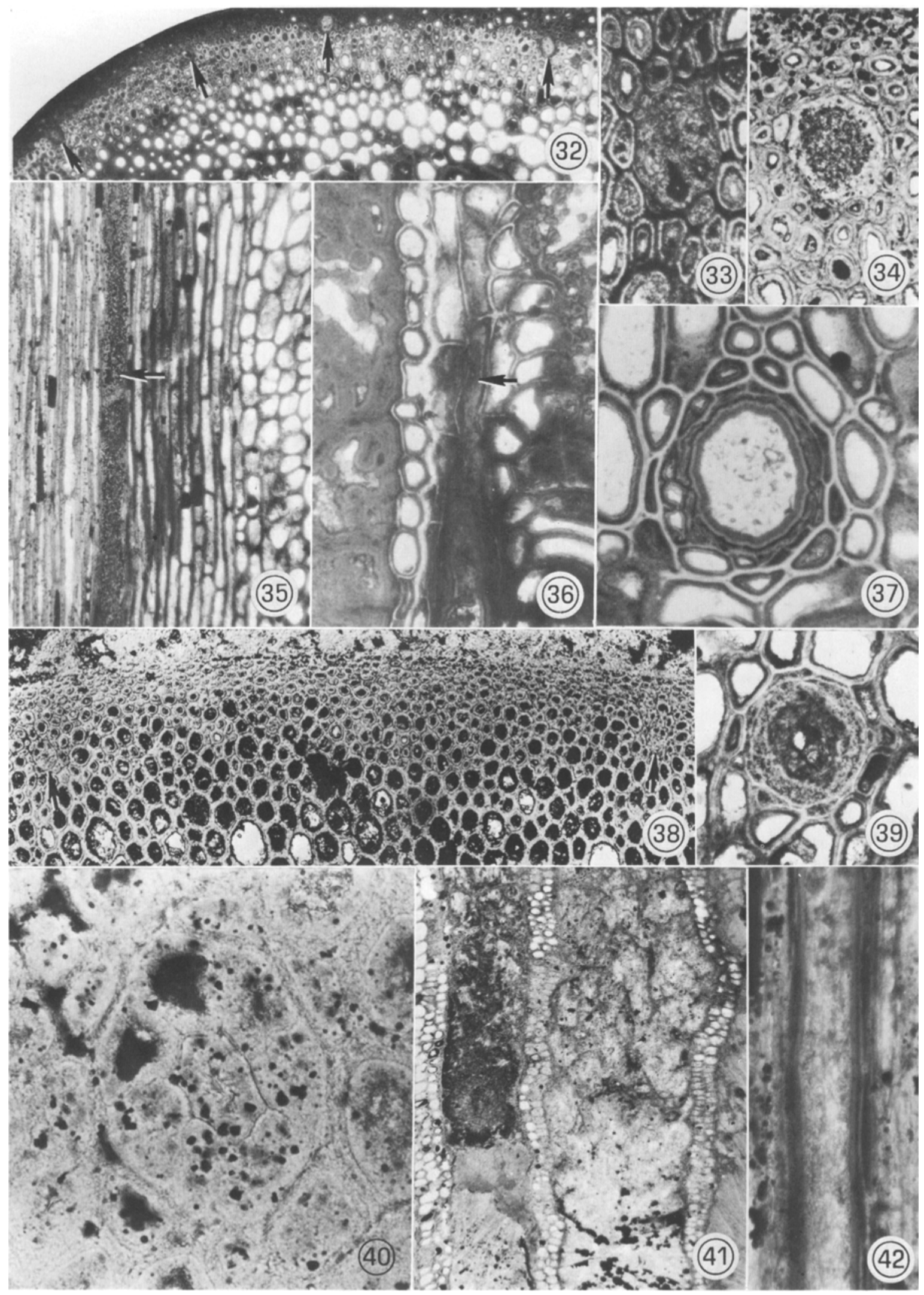


scribed as differing from $P$. perforatum in having smaller lacunae; but knowing now that $P$. perforatum is synonymous with $P$. reticulatum, and judging from the variation in lacuna size among my specimens, I consider this character, likewise, an inadequate basis for species delimitation. Clearly, there is insufficient information upon which to have based a new species. Indeed, one cannot be confident even of the generic identity of this specimen.

AERocortex KentUCKIENSIS-Two specimens, numbers 117 and 159 , exhibit many of the characteristics of Periastron. Two clear differences, and the impossibility at present of proving these specimens to be Periastron, lead me to designate them as a new genus. It is possible, however, that these specimens represent a basal region of the axis (petiole) denoted as Periastron. The rationale for this viewpoint will be presented subsequently.

Both specimens are fragmentary, but supplement each other (Fig. 4, 5, 45). Furthermore, they apparently represent two slightly different levels of an axis. The vascular bundles occur in a shallow arc through the central, parenchymatous region of the axes, much as in Periastron. One specimen (117) is characterized by two vascular bundles, of shallow, U-shaped, transverse configuration (Fig. 4). Each bundle is extended toward the center of the axis and the inner region of each is defined by grooves, characteristic of a level just below the divergence of bundle branching (Fig. 14, 45a). The other specimen (159; Fig. 5 ) is characterized by a similar arrangement of vascular bundles, the bundles being represented, however, only by one surface of the bundle sheaths (Fig. 15, 45b). There is evidence of four vascular bundles, two larger outer, and two smaller inner ones (Fig. 45b), the precise situation that would result from branching of the two bundles of specimen 117 .

Each vascular bundle apparently consisted of a central column of primary xylem enclosed by a region of fragile parenchymatous tissue, presumably containing the primary phloem. These tis- sues were bounded by a bundle sheath consisting of 3-5 layers of thick-walled, sclerenchymatous cells. In the fossilized condition of the axis, however, the xylem column seems to be in contact with the bundle sheath along one side, and there is a large cavity filled with mineral and organic debris between it and the bundle sheath on the opposite side (Fig. 4, 14). Only a few fragments of relatively uncompressed phloem-like tissue are to be found attached to the xylem. Careful observation, however, reveals a thin layer of highly compressed tissue between the xylem strand and bundle sheath on one side and between the mineral accretion and bundle sheath elsewhere. This suggests that the xylem strand was displaced and the surrounding parenchymatous tissue compressed during the process of mineral precipitation. Such displacement and tissue destruction is not uncommon in New Albany shale plant fossils.

Cells of the xylem are polygonal in transverse shape (Fig. 14) with a mean diameter of $77 \mu \mathrm{m}$. There is a gradual decrease in size toward the periphery of the xylem strand, but I have been unable to recognize distinct regions of protoxylem. The xylem has not been observed in longitudinal view.

Scattered throughout the central region of specimen 117 (Fig. 45a), and in the region between and immediately below the vascular bundles of specimen 159 (Fig. 45b), are secretory ducts. In specimen 159, these ducts extend into the region of air channels, but in neither specimen is there any evidence of their presence in peripheral tissues. Of similar, but somewhat variable size in the two specimens, the ducts average $211 \mu \mathrm{m}$ in transverse diameter. Each is enclosed by a narrow sheath of thick-walled cells, to the interior of which is evidence of at least one layer of very thin-walled cells-presumably secretory cells (Fig. 37, 39). In every observable detail, the morphology of these ducts is identical with those of Periastron.

A large part of the cortical region of both specimens is composed of a highly aerenchymatous tissue containing numerous, conspicuous air

Fig. 32-42.-Fig. 32-35, 38, 40-42. Periastron reticulatum. 32. Transverse view of outer cortex showing distribution of secretory ducts (arrows). Slide 121-4. $\times 32$. 33. Secretory duct exhibiting remnants of peripheral, thin-walled cells enclosed by a sheath of thick-walled cells. Slide 121-4. $\times 133$. 34. Secretory duct containing central column of dark, granular material. Slide 100-5. $\times 133$. 35. Longitudinal view of cortex showing sclerenchymatous outer cortex (left) that intergrades with more isodiametric cells (right) just outside the region of air channels. Note, also, the secretory duct (arrow). Slide $271 \mathrm{~L}-13 . \times 29$. 38. Transverse view of outer cortex of specimen named $P$. perforatum by Jeffrey and Scott (1914) showing secretory ducts (arrows). Slide $2898 \mathrm{~Eb}$ (British Museum of Natural History). $\times 48$. 40. Enlargement of secretory duct shown at left in Fig. 38 , illustrating single layer of large, thin-walled secretory cells. $\times 436$. 41. Longitudinal section, tangential to air channels, showing longitudinal continuity of channels and sectional views of the septae between channels. Slide $271 \mathrm{~L}-8 . \times 15.42$. Longitudinal view of secretory duct. Slide $271 \mathrm{~L}-14$. $\times 100 .-$ Fig. 36, 37, 39. Aerocortex kentuckiensis. 36. Longitudinally oblique view showing nature of cells (arrows) immediately surrounding secretory duct. Slide $159-17 . \times 56.37$. Transverse view of secretory duct similar to that shown in Fig. 36. Slide 159-7. $\times 133.39$. Secretory duct. Slide 117-1. $\times 133$. 


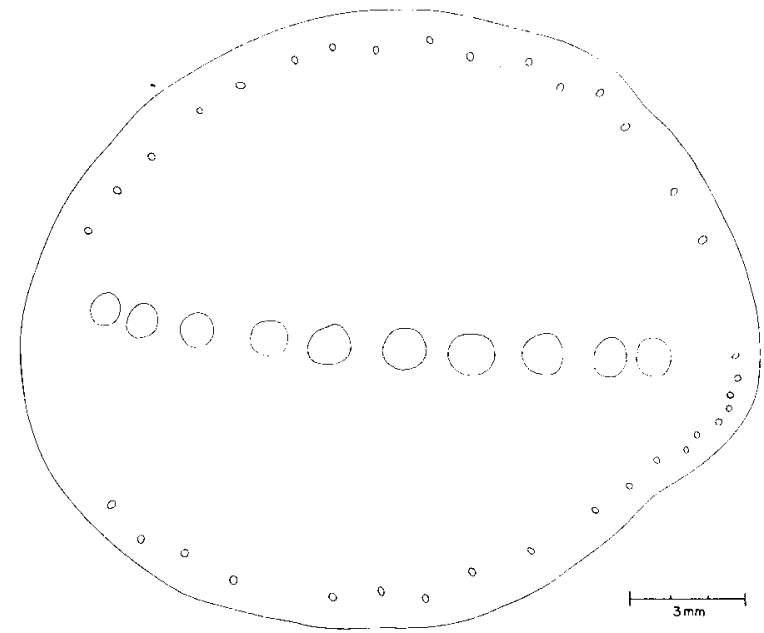

Fig. 43. Periastron reticulatum. Composite drawing indicating location and distribution of secretory ducts. Based on slides 271-1, 271-4, 271-7 and 27i-18.

channels; but this system of channels is apparently more extensive, occupying a greater percentage of the total volume of the axis, in specimen 159 than in 117 (Fig. 45a, b). Separating the channels are sheets of parenchyma tissue of varying thickness, thicker in specimen 117 which has a less extensive system of air channels and thinner in specimen 159 which has a very extensive system. In the latter, the cells of these sheets are transversely and longitudinally of very small dimension, their radial dimension being the greatest (Fig. 25). This region of aerenchyma is bounded by a relatively narrow peripheral layer of sclerenchymatous cells which, presumably, as in Periastron, is hypodermal although the epidermis is not preserved in either specimen.

Although very similar to Periastron in several features, these specimens differ conspicuously in the position of the secretory ducts. They are located peripherally in Periastron and centrally in these specimens. Another difference is the presence of two and four vascular bundles in specimens 117 and 159 , respectively, and five to ten or more in Periastron. The central region of parenchyma tissue in these specimens is broader than that in Periastron. In spite of the similarities, these differences, and the lack of proof of anatomy of this type and anatomy typical of Periastron in a single axis, compel me to establish new generic and specific names for these specimens.

Aerocortex kentuckiensis, n. gen. et sp. Fig. 4, 5, 14-16, 25, 36, 37, 45a, b

Combined diagnosis-Axis containing 2-4 vascular bundles, shallowly U-shaped (to circular?) in transverse configuration, embedded in a

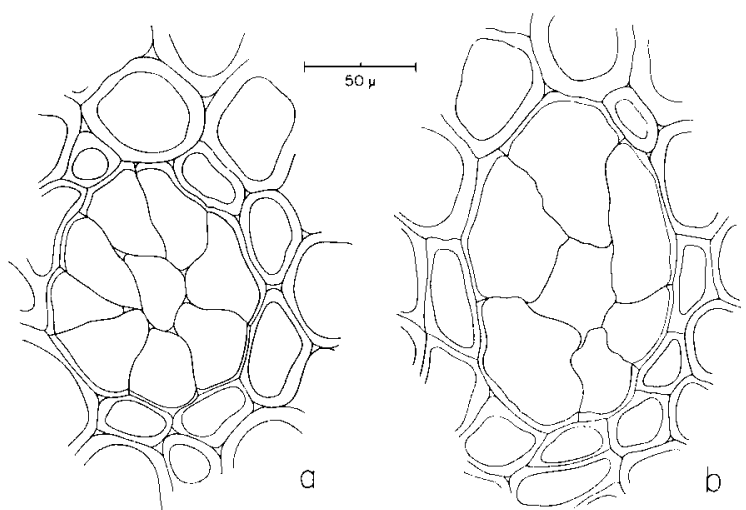

Fig. 44. Periastron reticulatum. a. Secretory duct with intact central cell. Slide $121 \mathrm{C}-0$. b. Secretory duct lacking central cell. Slide $121 \mathrm{C}-2$.

central parenchymatous tissue containing numerous secretory ducts. Central region enclosed by a broad zone of aerenchyma with numerous large air channels, bounded by a hypodermis of thick-walled cells. Concentric vascular bundles consisting of xylem surrounded by a thin-walled tissue, presumably phloem, enclosed, in turn, by a sclerenchymatous bundle sheath. Xylem cells $77 \mu \mathrm{m}$ in mean transverse dimension, polygonal and gradually diminishing in diameter toward the periphery. Secretory ducts ovoid to circular in transverse shape, 211 $\mu \mathrm{m}$ in mean diameter; enclosed by small, thickwalled cells, and consisting of, at least, a peripheral layer of very thin-walled parenchyma cells.

Types-Holotype, 62244; paratype, 62245. On file in the Museum of Paleontology of the University of Michigan, Ann Arbor.

Type locality-Roadside exposure, on east side of U.S. route 31E, 2.4 miles north of New Haven, Nelson County, Kentucky. Sanderson Formation (Falling Run member), New Albany Shale, Lower Mississippian.

Discussion-Whereas the central position of the secretory ducts and the small number of vascular bundles provide the primary bases for taxonomically separating Aerocortex from Periastron, the variation in these features in the two specimens of Aerocortex (117 and 159) suggests a possible explanation for the difference. Consequently, they provide a rationale for the hypothesis that these two organ genera represent different levels of the same biological entity.

In Periastron, variation and change in the number of vascular bundles through division and fusion have been demonstrated in this paper. If Periastron is a petiole, as has been previously 


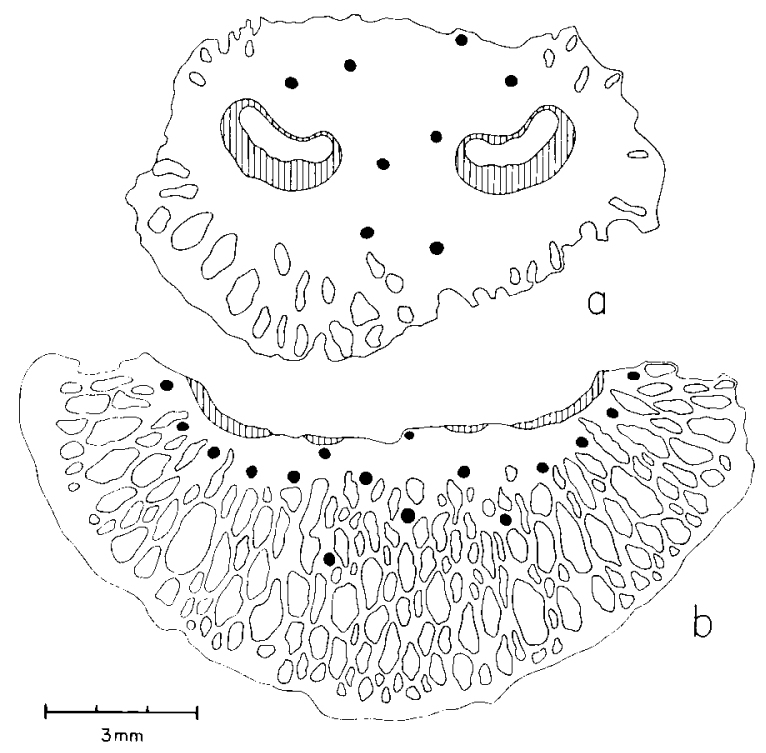

Fig. 45. Aerocortex kentuckiensis. a. Slide 117-1. b. Slide 159-7, supplemented by observations of transverse surface of embedded, unsectioned axis segment. Bundle sheaths lined, secretory ducts black.

suggested, the presence of only one or two vascular bundles in its base would not be surprising-indeed, might even be expected. Similarly there would probably be only a few secretory ducts, and these very likely would be located centrally in the petiole base. More distally the number of both vascular bundles and secretory ducts would increase.

Such changes seem to be reflected in Aerocortex, assuming that specimen 117 (Fig. 45a) represents a more basal region than specimen 159 (Fig. $45 \mathrm{~b})$. Significantly, perhaps, there is not only an increase in the number of secretory ducts, but also a change in their distribution and relative position. Whereas in 117 they form a central cluster, they seem, in 159, to be arranged in an irregular cylinder, and some are clearly located deep within the aerenchyma, and in a more peripheral position in relation to the vascular bundles. One would expect that even more distally in such an axis, the secretory ducts might comprise a peripherally located cylinder as in Periastron.

It is on the basis of such an analysis that I suggest that Aerocortex and Periastron might represent respectively, proximal and distal levels in the petiole of one taxon. The evidence which forms the basis for this analysis is largely circumstantial, however, and proof of common identity has not been provided.

In this study, I have had to deal with the problem of whether or not the variation exhibited in Periastron reflects more than one species. I have concluded that it does not. This is in some degree an arbitrary decision based on my belief that,

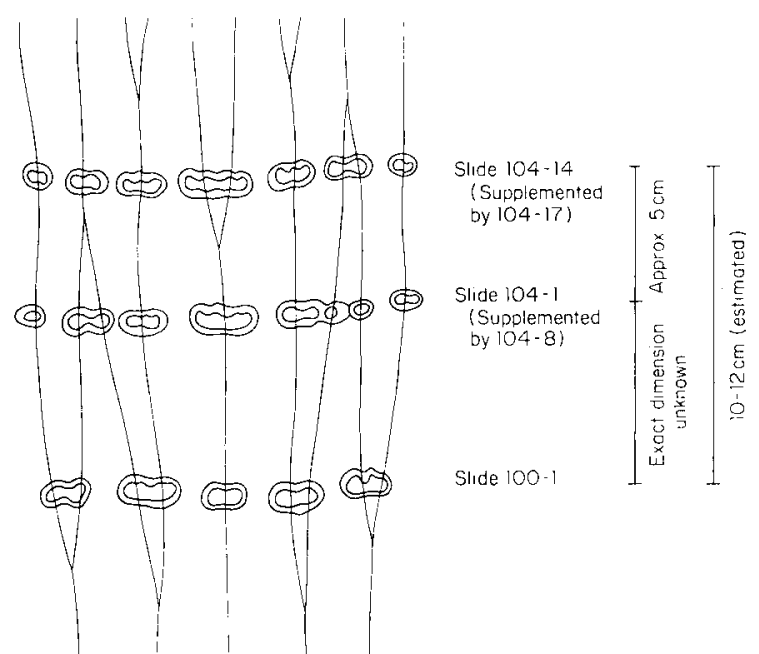

Fig. 46. Periastron reticulatum. Interpretation of the longitudinal pattern of vascular bundles superimposed on camera lucida drawings of the vascular bundles of three transverse sections. Note that, in relation to the transverse dimensions, the longitudinal dimension of the diagram is much reduced. Division anticipated on the basis of bundle morphology would result in ten bundles, a number of frequent occurrence in specimens of Periastron as exemplified in this study by specimens 121,158 . and 271 (Fig. 1-3). Other variations in the number such as 9 in Unger's (1856) specimen or possibly 11 in a specimen described by Scott and Jeffrey (1914) are apparently related to the levels and frequency of division and/or fusion of bundles in the axis. More basal levels of the petiole might be represented by Aerocortex (Fig. 4, 5, 45a, b) which is characterized by two or four bundles.

when confronted with such a problem involving many fragmentary specimens of an organ genus, and having no very satisfactory basis for making a decision, it is better to lump than to split. This, at least, prevents cluttering up the literature with more, probably biologically meaningless, names. There is, however, in this case, an objective basis for this decision as well.

I might have segregated specimens into two categories on the basis of vascular bundle form and number, those with five, transversely elongate bundles comprising one group, those with ten transversely circular bundles comprising the other. I was dissuaded from this course, however, in large part by the intermediate condition in specimen 104 in which division and fusion of bundles had resulted in variation of from 7 to 9 bundles, depending on the level, and of variation in bundle morphology from transversely circular to elongate and variously grooved. Other specimens add support to this viewpoint. Importantly, the type specimen of $P$. reticulatum is characterized in cross section by 9 bundles, 8 circular ones and a central one that is elongate and shallowly U-shaped (Unger, 1856), essentially identical to the larger bundles of my specimen 100 (Fig. 6). Furthermore, the pairing and variable spacing 
of bundles in several of my specimens (Fig. 1-3) and the fact that two closely adjacent bundles share a common bundle sheath (Fig. 20, 22) suggest fusion and/or division at some level(s) within the axis. Fusion would lead to elongate bundles, and both fusion and division, of course, would result in variation in number.

Since categorization on the basis of vascular bundle form and number is clearly untenable, and variation is continuous in the only other conspicuously variable character-the transverse dimensions of the air channels-I find no justifiable basis for species segregation.

The nature of Periastron as a petiole seems to be generally accepted, but there has been, understandably, almost no strong position taken on its taxonomic affinity. Evidence provided herein suggests that the vascular system of this petiolelike axis which consisted of dividing and anastomosing bundles became more extensive distally. These features, and the absence of any evidence of traces to lateral appendages suggest that Periastron represents the petiole of a large, simple, leaf. The dimensions of the petiole segments indicate that this leaf was very large, perhaps several to many decimeters long. The occurrence of petiole segments $2-6 \mathrm{~cm}$ long by $1-1.5$ $\mathrm{cm}$ in diam, and the evidence that several different levels within a petiole are represented among my specimens suggests that the petiole was quite long, comprising a major part of the leaf.

There is one compression specimen of Devonian age (Psygmophyllum gilkineti) that, on the basis of leaf size and form, could represent the same plant as Periastron. Leclercq (Leclerca and Béllière, 1928) described the leaf of $P$. gilkineti as consisting of a slender petiole, 20 to 33 $\mathrm{cm}$ long, bearing distally a flabelliform blade $10-14 \mathrm{~cm}$ long and $10-15 \mathrm{~cm}$ wide. She did not provide data on petiole width, but based on her figures, drawn to scale, and other dimensions, it is apparent that petiole diameter varies from approximately $1-1.5 \mathrm{~cm}$. These features are consistent with the known and postulated features of Periastron. It is, however, impossible on these bases to confirm positively the identity of these genera in the absence of information on internal structure of Psygmophyllum gilkineti and the form and venation pattern of the blade of Periastron. Psygmophyllum gilkineti is, furthermore, of Middle Devonian age although the genus is considered to extend throughout the Paleozoic. There is no evidence that any Psygmophyllum was aquatic or semi-aquatic as one suspects, because of its extensive system of air channels, Periastron was. Indeed, Leclercq felt that $\boldsymbol{P}$. gilkineti was a woody plant of arborescent or shrubby habit, but the basis for this view is not clear.

Neither the possible identity of Periastron and
Psygmophyllum nor the anatomical details of Periastron documented herein form a basis for an accurate determination of the systematic position of Periastron. One newly demonstrated feature. the fine reticulate pattern of the wall of tracheary (and other?) cells is probably of no taxonomic value since it, or an apparently comparable feature, occurs in Psilophyton dawsonii (Banks, Leclercq, and Hueber, 1975), lycopods such as Lepidodendron (Wesley and Kuyper, 1951), Levicaulis (Beck, 1958), among others, and even angiosperms such as Platanus and Euptelea (Barghoorn and Scott, 1958). The distinct possibility that the finely reticulate appearance of the wall in Periastron has resulted from wall degradation or is an artifact of crystal form might apply as well to other fossil genera in which a similar wall feature has been described. The secretory canals of Periastron and Aerocortex are of no assistance at present, but ultimately may provide the basis for identification with a major taxon. The aerenchymatous cortex which suggests an aquatic or a semi-aquatic habitat is, likewise, of no apparent taxonomic value. A similar tissue characterizes an undescribed specimen of Clepsydropsis in my collection.

After considering all of its features and comparing it with several Devonian and Lower Mississippian groups, I can conclude only that Periastron exhibits a highly distinctive set of characters, unlike that of any well-known group. There is at present no objective basis for assigning it to a major taxon, and it must, therefore remain Incertae Sedis. Hopefully, the extensive detail presented herein will provide a basis for future correlation with specimens of different and/or more complete preservation, allowing ultimately a comprehension of its structural relationship, if any, with Aerocortex, its systematic position and its phylogenetic significance.

\section{LITERATURE CITED}

Banks, H. P., S. LeclercQ, and F. M. Hueber. 1975. Anatomy and morphology of Psilophyton dawsonii, sp. n. from the late Lower Devonian of Quebec (Gaspé), and Ontario, Canada. Palaeontogr. Amer. 8: 77-127.

Barghoorn, E. S., AND R. A. SCotT. 1958. Degradation of the plant cell wall and its relation to certain tracheary features of the Lepidodendrales. Amer. J. Bot. 45: 222227.

BECK, C. B. 1958. Levicaulis arranensis, gen. et. sp. nov., a lycopsid axis from the Lower Carboniferous of Scotland. Trans. R. Soc. Edinb. 63: 445-457.

Bertrand, Paul, R. Böhm, and Paul Corsin. 1935. Découverte d'une flore dans les Lydiennes du Carbonifère de la Montagne-Noire a Saint-Nazaire-de-Laderez (Hérault). C. R. Acad. Sci. Paris 200: 1344-1345.

BöHM, R. 1935. Etude sur la flore de l'horizon a Lydiennes de la base du Carbonifére de la Montagne Noire. Imprimerie de la Charité, Montpellier, p. 1-29.

Campbell, Guy. 1946. New Albany shale. Bull. Geol. Soc. Amer. 57: 829-908. 
Cross, A. T., And J. H. Hoskins. 1951. Paleobotany of the Devonian-Mississippian black shales. J. Paleontol. 25: 713-728.

HASS, W. H. 1956. Age and correlation of the Chattanooga shale and the Maury formation. U.S. Geol. Surv. Prof. Paper 286: $1-47$.

LeclercQ, S., ANd M. Béllière. 1928. Psygmophyllum Gilkincti. sp. n.. du dévonien moyen à facies Old Red Sandstone de Malonne (environs de Namur, Belgique). J. Linn. Soc. London, Bot. 48: 4-14.

Read, C. B. 1936. A Devonian flora from Kentucky. J. Paleontol. 10: 215-227.

Scott. D. H., ANd E. C. JefFrey. 1914. On fossil plants, showing structure, from the base of the Waverley shale of Kentucky. Philos. Trans. R. Soc. London 205B: 315373.

Solms-Laubach, H. 1896. Ueber die seinerzeit von Unger beschriebenen strukturbietenden Pflanzenreste des Unterculm von Saalfeld in Thüringen. Abh. König. Preuss. Geol. Landes. 23: 1-100.

UNGER, F. 1856. Zweiter Theil. Schiefer und Sandsteinflora. In R. Richter and F. Unger. Beitrag zur Paläontologie des Thüringer Waldes. Denkschr. Kaiser. Akad. Wiss. Wien 11: 139-186.

Wesley, A., AND B. KuYper. 1951. Electron-microscopic observations on the xylem elements of a fossil plant Nature 168: 137-140. 